\title{
E-Government between Developed and Developing Countries
}

http://dx.doi.org/10.3991/ijac.v5i1.1887

\author{
S. A. Nawafleh ${ }^{1}$, R. F. Obiedat ${ }^{2}$, O. K. Harfoushi ${ }^{2}$ \\ ${ }^{1}$ University of Petra, Amman, Jordan \\ ${ }^{2}$ University of Jordan, Amman , Jordan
}

\begin{abstract}
E-government aims to offer services the country's' communities both in public or private sectors by using the ICT tools to reduce the cost and times by eradication of manifestations of routines and bureaucracy. All countries around the world are seeking to implement and diffuse egovernment services, especially the developing countries, and to do that they have to overcome a range of factors that prevent the effective implementation of e-government in the countries.
\end{abstract}

This paper discusses and analyzes E-government topics and revolves around the most important factors behind the success of this program, and tries to analyze and study the Egovernment program in Finland as a developed country, and Saudi Arabia as a developing one. It aims to find out the most important strategies that have been used to overcome the challenges; these factors \& strategies, including such as infrastructure, technical, social, political and cultural in order to study some of these factors in each of them and try to make a comparison between to contribute to the success of the program in other developing countries, as well as to beneficial from developed country's experiences in this field. The reason behind selecting Finland and Saudi Arabia is the qualitative leap made by both of them, especially Saudi Arabia as a developing country and their success in the program with a record time.

Index Terms-E-government, Successes Factors, Developed Countries, Developing Countries.

\section{INTRODUCTION}

E-government has become one of the vital topics in all over the world; all countries have started applying egovernment in their governments,' even developing countries. As it is known, all countries began focusing on this topic because it serves all citizens in the country. Moreover, it will save the country a lot of money, achieve greater progress, exploit the time and effort of the public sector employees, provide accurate and timely completion of transactions, alleviate the pressure on the workers and facilitate suffering and fatigue on the citizens in various places and cities in any country [13].

The increasing of using this topic started with the ICT revolution. This revolution has increasingly encouraged changes in many aspects related to people daily life around the world, and is also changing the way in which governments around the globe interact with their citizens, businesses, government agencies, employees, and other stakeholders [2].

In general, these changes are rapidly being referred to E-Government Generally, E-Government, as a new and emerging area of interest in the field e-businesses employs ICTs to enhance the access and delivery of government information and services to citizens, businesses, government employees, and other agencies. To this end, more governments around the globe have been inspired by these enormous changes and swift advances in ICTs: raising hopes to reduce operating costs for both businesses and citizens; providing citizens and businesses with more convenient access to online government services; improving the quality of government services' delivery; and increasing effectiveness and efficiency in the public sector organizations [8].

According to some international reports and studies, Egovernment has become important to national and international communities, providing these communities with many potential opportunities to improve the quality of government services to citizens. Citizens should be able to get services or information in minutes or hours, versus days or weeks. Citizens, businesses and governments should be able to file the required reports without having to hire accountants and lawyers. Government employees should be able to do their work as easily, efficiently and effectively as their counterparts in the commercial world [16].

\section{MethodOLOGY}

\section{A. Problem}

Most of the previous studies on E-government topics were focusing on its importance, the advantages and constraints to citizens, business, government and its employees. This paper will analyze the main factors which play a significant role in the success of E-government program and trying to know the probability of successfully applying e-government program in the developing countries, which have similar conditions to the developed countries, with comparing all these feasibilities with one or more of developing countries specially because these factors play a big role in the success of this program and in the developed countries.

The main problem of this paper will be focusing on the study and analysis of these factors through these factors. This study highlights the problem of developing countries, which are suffering, and trying to absorb and overcome the political, cultural and social transformation with the benefit of scientific and technological advances, by comparing with developed countries in the field of E- government and ICTS tools. The paper will analyze case studies through answering some questions relating to this topic such as: 
- What are the factors that can support the design, creation and implementation of an E- Government program in the developed country such as (infrastructure, technical, political, cultural, and social factors)?

- Can a comparison be made in the E government field between developed countries and developing countries?

\section{B. Purpose}

- Highlights the developed countries experience in the field of E-government.

- Attempts to make a comparison between developed and developing countries and attempt to benefit from developed countries experience.

- Identifies the main success factors, which play a big role in the E-government of developed countries.

\section{Data Analysis (Qualitative)}

This paper uses the qualitative data analysis through analyzing some previous studies which are related to the e-government in developed and developing countries in various countries around the world wich is focusing on Finland as a developed country and KSA as a developing country; in order to highlight the main strategies, factors, and challenges by comparing e-government program between them, identifying the best strategies and factors in order to overcome these challenges as well as using these strategies and success factors to enhance and improve egovernment performance in the other countries.

\section{E-GOVERNMENT OVERVIEW}

\section{A. Litterature Review}

This part of this paper explains the definition of Egovernment, the importance of E-government, the main partners of government and factors which play a significant role in the success of an E-government program according to most of the international initiatives in Egovernment field, especially in the developed countries.

E-Government defined as the electronic interaction transaction and information exchange between the government, the public sector, citizens, businesses and employees in order to access to efficient and effective service delivery [5].

According to the E-Government Strategy [7], EGovernment defined as using ICTs systems to transform relations with citizens, business sector, government agencies and employees to promote the empowerment of citizens, improving service delivery and enhance accountability, increase transparency, improve government performance efficiency.

E-government is the continuous improving quality of service delivery, improving the participation inside government, through using the information technology tools, the Internet and the ICTs applications. This includes Government to Citizen, Government to Employee, Government to Business, and Government to Government. This means the relation between them internal relations like government to government and external relations like a government to business and citizens [8].
According to, all previous studies in the E-government topic E-government can be defined as a set of mutual processes between government and citizens, government and business, government and employees, and according to what they mentioned above, the government could directly provide electronic services via the internet; To improve services for citizens in order to increase effectiveness and efficiency in the public and private sector in the country. This means E-government aims to use the internet applications in order to provide, access to all electronic services which they need.

\section{B. E-Government Partners}

According to, all previous definitions for E- government we are noting that there are several partners with Egovernment in its process including two internal and external partners, each of them able to benefit from these services those partners are [16]:

- Government to Citizens (G2C).

- Government to Business (G2B).

- Government to Government (G2G).

- Government to Employees (G2E).

\section{E-Government Benefits}

There are several benefits for E-government programs; any country is looking for achieving these goals or benefits in order to serve all partners in the countries. These benefits are summarized as a following [3]:

1. Cost reduction and efficiency gains: through using all internal and external services online that means decreases the processing costs of many activities as well as will increase the government efficiency.

2. Quality of service delivery to businesses and customers: E- government mean to enable access to all services by using the internet, as well as services online will enhance reducing the bureaucracy process inside the government, improving the procedures and offering fast and convenient transactions.

3. Increase the capacity of government: E-government aims to use ICT tools to support organizations to organize their work inside and outside the organization, leading to greater efficiency, effectiveness and further improve the type of services provided in the public sector or the business sector, as well as assistance in making decisions.

4. Network and community creation: E-government is seeking to create an atmosphere of interaction between all partners in e-government through the exchange of information on a network and an integrated and harmonious community.

\section{CASE STUdies ANALysis}

\section{A. Factors Affecting E-Government In Developed \& Developing Countries}

Through access to United Nations reports in the egovernment field [16], it is noticed the presence of a huge gap between developing and developed countries in the egovernment field, and we will highlight those differences on several key factors analyze throughTable I. 
TABLE I.

COMPARING DIFFERENT FACTORS BETWEEN DEVELOPED \& DEVELOPING COUNTRIES [4, 9]

\begin{tabular}{|c|c|c|}
\hline & Developed countries & Developing countries \\
\hline Infrastructure & $\begin{array}{l}\text { Good current infrastruc- } \\
\text { ture \& High internet } \\
\text { access for employees } \\
\text { and citizens }\end{array}$ & $\begin{array}{l}\text { Bad current infrastruc- } \\
\text { ture \& Low internet } \\
\text { access for employees } \\
\text { and citizens }\end{array}$ \\
\hline $\begin{array}{l}\text { History and } \\
\text { Culture }\end{array}$ & $\begin{array}{l}\text { Government and econ- } \\
\text { omy developed early, } \\
\text { economy growing at a } \\
\text { constant rate, productiv- } \\
\text { ity increasing, high } \\
\text { standard of living, long } \\
\text { history of democracy. }\end{array}$ & $\begin{array}{l}\text { Government usually not } \\
\text { specifically defined; } \\
\text { economy not increasing } \\
\text { in productivity, economy } \\
\text { not growing or increas- } \\
\text { ing productivity; low } \\
\text { standard of living, short } \\
\text { history of democracy }\end{array}$ \\
\hline $\begin{array}{l}\text { Technical } \\
\text { Staff }\end{array}$ & $\begin{array}{l}\text { Has a current staff, } \\
\text { needs to increase tech- } \\
\text { nical abilities and to hire } \\
\text { younger professionals. } \\
\text { current staff would be } \\
\text { able to define require- } \\
\text { ments for development }\end{array}$ & $\begin{array}{l}\text { Does not have a staff, or } \\
\text { has very limited in house } \\
\text { staff, current staff may } \\
\text { be unable to define } \\
\text { specific requirements. }\end{array}$ \\
\hline Citizens & $\begin{array}{l}\text { High Internet access and } \\
\text { computer literacy; still } \\
\text { has digital divide and } \\
\text { privacy issues, more } \\
\text { actively participate in } \\
\text { the governmental pol- } \\
\text { icy-making process. }\end{array}$ & $\begin{array}{l}\text { Low internet access and } \\
\text { citizens are reluctant to } \\
\text { trust online services; few } \\
\text { citizens know how to } \\
\text { operate computers, less } \\
\text { active participation in } \\
\text { the governmental policy- } \\
\text { making process. }\end{array}$ \\
\hline $\begin{array}{l}\text { Government } \\
\text { Officers }\end{array}$ & $\begin{array}{l}\text { Decent computer liter- } \\
\text { acy and dedication of } \\
\text { resources; many do not } \\
\text { place e-government at a } \\
\text { high priority. }\end{array}$ & $\begin{array}{l}\text { Low computer literacy } \\
\text { and dedication of re- } \\
\text { sources; many do not } \\
\text { place e-government at a } \\
\text { high priority due to lack } \\
\text { of knowledge on the } \\
\text { issue. }\end{array}$ \\
\hline
\end{tabular}

\section{B. Analysis Of The E-Government Program In Finland}

According to the World Bank report [10] on Egovernment, Finland is considered one of the best countries in all over the world in E-government applications; it has good infrastructure such as ICT tools, technical methods, human resources system, and cultural and social history. For that reason, any developing country will benefit from Finland's experiences in the E-government field. This part of the study is explained and represented briefly some factors behind Finland E-government succeed, Table II explains the factors' challenges which faced Egovernment in Finland and the best way to overcome these challenges

According to, previous template, it represented all the Finland government efforts to having best E-government program. Finland has best technologies in the Egovernment field can be summarized by [14]:

- Electronic ID card was created in 1999 in order to all Finnish citizens to get the public infrastructure service its valid for three-year citizens be able to use it as a traveling ID card, E banking, and insurance ID card in the 19 countries of European Union.

- Digital signature is agreement between Finnish government and Estonia government to improve the harmonies of the concepts and practice regarding on digital signature and documents format and exchange between two countries according to European legislations as well as international standard.
TABLE II.

E-GOVERNMENT CHALLENGES FACTORS IN FINLAND

\begin{tabular}{|c|c|}
\hline $\begin{array}{l}\text { Challenge \& } \\
\text { barriers factors } \\
\text { in Finland }\end{array}$ & Overcome strategies in Finland \\
\hline $\begin{array}{l}\text { Political, Legis- } \\
\text { lative and } \\
\text { regulatory [6] }\end{array}$ & $\begin{array}{l}\text { For access to E- government program effectively, } \\
\text { the Government enacted rules and regulations to } \\
\text { implement the program and political decision- } \\
\text { making in order to coordination between minis- } \\
\text { tries and government departments and standardi- } \\
\text { zation of procedures and regulations to facilitate } \\
\text { the passing of information and data as well as } \\
\text { government has found a set of policies and regu- } \\
\text { lations for the protection of information and elec- } \\
\text { tronic data. }\end{array}$ \\
\hline $\begin{array}{l}\text { Public reform } \\
\text { imperatives } \\
\text { [11] }\end{array}$ & $\begin{array}{l}\text { One of the most important factors in the Finland } \\
\text { government was reforming public administration } \\
\text { to improve public services, the aim of this strat- } \\
\text { egy to build a framework in order to introduce E- } \\
\text { government and to improve public administration } \\
\text { services by reducing transaction costs and creat- } \\
\text { ing an open information system. Reform was } \\
\text { focusing mainly on the decentralization \& ICT } \\
\text { tools system. }\end{array}$ \\
\hline $\begin{array}{l}\text { Promotion of } \\
\text { the information } \\
\text { society [12] }\end{array}$ & $\begin{array}{l}\text { Finland's government has long information soci- } \\
\text { ety from 1970s. Finland's government started } \\
\text { identifying this strategy in1990. It was including: } \\
\text { Information technology and information networks } \\
\text { in order to renewal PPS. The information industry } \\
\text { became an important sector of economic activity } \\
\text { in Finland. Everyone had the opportunity and } \\
\text { basic skills to use the services of the society in- } \\
\text { formation, Finnish information infrastructure to } \\
\text { be competitive and capable of providing high- } \\
\text { quality services. }\end{array}$ \\
\hline $\begin{array}{l}\text { Human Re- } \\
\text { source Man- } \\
\text { agement }\end{array}$ & $\begin{array}{l}\text { HRM is the most important factor in any project } \\
\text { in the organizations. for that reason, one of the } \\
\text { successes' factors in the E-government of Finland } \\
\text { is the Government's interested in human re- } \\
\text { sources, designs and development of all methods } \\
\text { and means for that success, as well as the gov- } \\
\text { ernment concerned with training and rehabilita- } \\
\text { tion workers in order to find a suitable system for } \\
\text { workers and the restructuring of salaries and } \\
\text { incentives.. }\end{array}$ \\
\hline $\begin{array}{l}\text { Budgetary \& } \\
\text { finance barri- } \\
\text { ers [12] }\end{array}$ & $\begin{array}{l}\text { One of the biggest challenges, which face any } \\
\text { project, is a financial obstacle. This factors that } \\
\text { the Government had scoffed where the Finnish } \\
\text { part of its budget for the e-government program } \\
\text { paved the infrastructure in the ICT field, change } \\
\text { public administration and put the budget in order } \\
\text { to increase the incentives for all Access to elec- } \\
\text { tronic services to all parts of the Finland. }\end{array}$ \\
\hline $\begin{array}{l}\text { Digital divide } \\
\text { [14] }\end{array}$ & $\begin{array}{l}\text { One of the most important factors that were play- } \\
\text { ing a big role in Finland E- government is digital } \\
\text { divide. Finland has been doing well in terms of } \\
\text { providing access to ICT, particularly the internet, } \\
\text { and possession of information technology still } \\
\text { differ markedly across generations, family types } \\
\text { and regions. Rural connectivity projects have } \\
\text { strengthened collaboration among municipalities } \\
\text { and fostered partnerships between public and } \\
\text { private actors, as in other countries with high ICT } \\
\text { penetration, closing the digital divide in Finland } \\
\text { now seems to depend increasingly on citizens' } \\
\text { own choices. In addition to improved access and } \\
\text { cost, computer and the internet use will depend } \\
\text { on citizens' perceptions of the value-added of } \\
\text { online services. Thereby further raising the stakes } \\
\text { for improving e-government. }\end{array}$ \\
\hline
\end{tabular}


- Citizen portals are lunched in 2002 as a single access to all public information , public forums and services

- ID card for E-government employees: this service started in Finland in 2006. These photo cards included qualified certificate enabling identification to log into information networks, including users' usage rights, e-mails and other documents and providing them a binding and undisputable signature.

- KuntaIT is a new card that was created by the interior ministry. It will be tasked with coordinating the compatibility of e-government services between municipal and regional authorities.

- Wap site for Finnish travellers was created by the ministry of foreign affairs in order to draw on travel safety information published in a website. It can be used by mobile to provide all information, which are easily displayed by the ministry.

- The combined electronic ID, for health insurance card, was created in 2004 in order to allow to all Finnish citizens request their insurance data by using ID card.

\section{Analysis Of The E-Government Program In KSA}

Several factors were taken into account to measure the success of the e-government program in Saudi Arabia, such as: political, social, cultural and legislation factors. These factors are analyzed and explained precisely the extent of its contribution and how to surmount in order to reach a successful program $[15,17]$ :

\section{E-GOVERNMENT Vision, STRATEGIES \& OBJECTIVES IN KSA}

E-government vision in KSA represented [17]:

By the end of the year 2010, the ultimate vision of the e-Government in KSA in the ability of any Saudi citizen access to all services needed by the electronic ways and secure means:

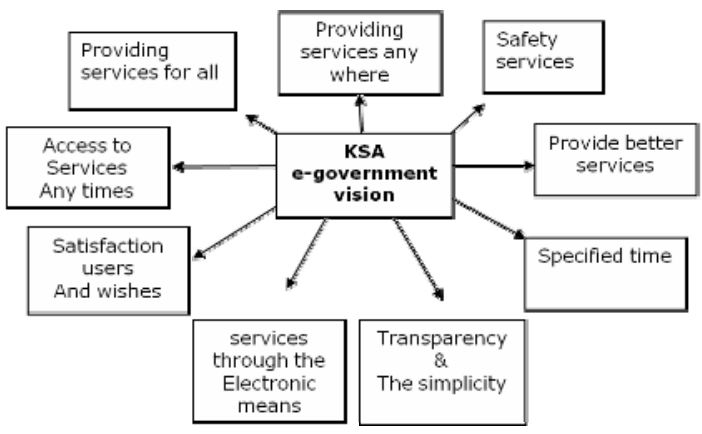

Figure 1. Saudi Arabia e-government vision [17]

\section{E-GOVERNMENT OBJECTIVES}

There are a set of important goals, any e-Government program aims to reach to these goals, and some of these goals are summarized as a following [17]:

- Raising the public sector's productivity and efficiency.

- Providing better and more easy-to-use G2C services for individual citizens and G2B for business customers.

- Increasing return on IT investments.

- Enhancing the integrity and readily access of government data.
TABLE III.

E-GOVERNMENT CHALLENGES FACTORS IN KSA

\begin{tabular}{|c|c|}
\hline $\begin{array}{l}\text { Challenge \& barri- } \\
\text { ers factors in KSA }\end{array}$ & Overcome strategies in KSA \\
\hline $\begin{array}{l}\text { Social and Culture } \\
\text { factors }\end{array}$ & $\begin{array}{l}\text { KSA is considered the largest Arab, Islamic } \\
\text { country. It is the first reference to all of } \\
\text { them because it includes the Islamic sancti- } \\
\text { ties; the culture in KSA is preventing the } \\
\text { work of Saudi women beside men at the } \\
\text { same places, but by using ICT tools, Saudi } \\
\text { Arabia overcame this problem by making } \\
\text { the dealing between them electronically } \\
\text { through using the application of e- } \\
\text { government, even in outside the scope of } \\
\text { the work; women can access to any service } \\
\text { that is electronically. Moreover, some peo- } \\
\text { ple are claiming that technology have dis- } \\
\text { advantages. Here we can exploit the posi- } \\
\text { tive aspects and leave the disadvantage } \\
\text { parts, as well as KSA was suffering from } \\
\text { the problem which is the tribal system in } \\
\text { their dealings with citizens in all ministries } \\
\text { and departments, through using of the e- } \\
\text { government program KSA overcame all of } \\
\text { these traditional phenomena such as helping } \\
\text { the relatives and friends in their services. }\end{array}$ \\
\hline Economic factors & $\begin{array}{l}\text { The second success factor in any experience } \\
\text { for e-government, which it needs to take in } \\
\text { the consideration, is the economic factors in } \\
\text { any country because these factors are play- } \\
\text { ing a big role in the success of this project. } \\
\text { Saudi Arabia has an important resource. It is } \\
\text { oil. The existence of this economic factor } \\
\text { contributes significantly to the success of } \\
\text { the program and in any other country may } \\
\text { have an economic factor contributing to } \\
\text { improve and enhance e-government pro- } \\
\text { gram. }\end{array}$ \\
\hline $\begin{array}{l}\text { Reforming the } \\
\text { Public Sector: }\end{array}$ & $\begin{array}{l}\text { E-government team in KSA has taken this } \\
\text { factor into their consideration when they } \\
\text { started building E-Government Program. } \\
\text { The importance of this factor is the need to } \\
\text { create any change in the public sector, for } \\
\text { example, to apply any new technology or } \\
\text { changes within the organization, such as E- } \\
\text { government implementation in the country } \\
\text { that is based on providing services elec- } \\
\text { tronically by using ICT tools. We need to } \\
\text { equip the public sector and its employees by } \\
\text { training in order to use this new technical, } \\
\text { to deal with citizens and customers by using } \\
\text { best way as well as to accept the idea of } \\
\text { change. In the case, the most prominent } \\
\text { things that have been taken in the E- } \\
\text { government experiment are changing the } \\
\text { regulations and rules in order to implement } \\
\text { these changes. }\end{array}$ \\
\hline Political factors & $\begin{array}{l}\text { These factors are playing an important role } \\
\text { in all parts of the country's policies and } \\
\text { strategic plans, political factors, including } \\
\text { some sub factors such as change of radical } \\
\text { regulations and rules inside the countries to } \\
\text { enhance the implementation of any new } \\
\text { strategic or plan, for example, the imple- } \\
\text { mentation of ICT tools in the organizations } \\
\text { in order to apply E-government program } \\
\text { inside the country as well as need to assist } \\
\text { employees within the organizations and } \\
\text { facilitate the implementation procedures. }\end{array}$ \\
\hline
\end{tabular}


KSA E-government program includes three main projects [17]:

- E-payment gateway: It aims to facilitate electronic payment between governments to business, business to business as well as payments between government and citizen.

- Smart card: It is a digital system or chips aims to store all citizens' data by using thumb prints such as an ID card, health and driving records.

- MOI: it is a portal in which the citizens can obtain identification cards and passports as well as the driving license and any certificates may be required by citizens.

\section{DISCUSSION}

Through analyzing previous cases in Saudi Arabia and Finland and access to the most important challenges, those developing and developed countries in e-government in order to highlight the most important of those factors that have faced both of them, as it highlighted the social, cultural, political factors and public sector reforming. Moreover, previous analysis highlighted the most important success factors and strategies that have contributed to overcome, including to find strong infrastructure, taking into account the importance of the social and cultural changes in order to implement the e-government program.

As well as the analysis focused on the using of scientific methods, technical change and analyzed the most important e-government strategies which are using to enhance e-government performance, as well as previous analysis highlighted the results and electronic services resulting from these programs, such as electronic portals at the internal and external of the country.

We are noting that both of them have faced challenges, for example, Finland has faced barriers, challenges, but it was able to overcome these challenges by used modern technical. It started with the education system in order to overcome the cultural, social challenges by reformed Finland's education system as well as it overcame technical, political factors by found some rules and regulations in order to improve and enhance Finland e-government's program.

Finland has the modern e-government program it is one of the best e-government programs around the world, and all the developing countries may benefit from Finland's experiences in this field.

About e-government in KSA, The main strategic plan for KSA e-government focused on building a strong infrastructure and strategy to be able to absorb all the changes in the E-government field and this strategy based on the provisions of the interdependence of all ministries and organizations in the country.

This strategy included two phases. The first one included two years has been aimed to achieve quick results based on reducing the time and effort, And the second one has included a period of five years has included the identification of the most important goals and identified the main electronic gates, priorities, major policies, and regulations $[15,17]$.

The project implementation aims to electronic governmental services deliver and a coordinating based on linking all ministries and government departments based on a decentralized in order to provide services and oversee the implementation of these strategies called (yesser). This project is responsible for the e-Government Program implementation in Saudi Arabia.

One of the main important strategies of the Saudi Arabia E-government program is (governance protects). Tis policy, which is responsible about all E-government data and information input, as well as the ability to deal with it by users in order to create a good mechanism to protect the implementation of electronic transactions; such as the availability of models and forms of service.

This policy is based on an integrated program aims to policy development in order to reach to protect information security, update some information, documentation, risks protection policy in order to protect data and information electronically, face technological progress in the IT fields include these risks, the loss of confidential data or lack of it, as well as the organize of information security policy, Human resources policy includes the appointment, training of personnel, change the duties of work, as well as the policy of entry included the ability to enter some information, optimal use and knowledge of e-mail services, mechanisms for encryption and password storage mechanisms, physical security policy, environmental policy, management of communications, policy of processes, information systems acquisition, development and maintenance policy [15].

According to previous analysis, there are several success factors, strategies that are playing a big role to improve E-government performance in the developed and developing countries. Each country has to take in the consideration these factors in order to build the e-government program. These factors are including e-government infrastructure, exploitation and improving employees capabilities inside governmental organizations, developing educational systems and Government officers, as well as there are several challenges have faced both of countries relating to previous factors such as political, social, cultural, technical, reforming public sector and human resources. Each country must overcome previous challenges in order to enhance, improve e-government program in their government.

\section{VIII.CONCLUSION}

E-government can be greatly affected by several important factors, such as political, cultural and religious factors. These factors must be taking into account and analyze thoroughly, especially when we are looking for efficient and successful implementation of an e-government program in developing countries.

Previous analysis of these factors has been through the analyzed e-government program in Saudi Arabia as a developing country. This study described a range of benefits and lessons learned in the field of capacity utilization and to manage successfully. These factors like what Saudi Arabia has done to overcome these challenges by benefit from developed countries experiences these factors summarized as a following [1]:

- As a Political factor, Saudi government has to enact rules and legislation necessary to implement the egovernment program, such as E-government the formation of a special committee to follow up on top of implementation and facilitate the formation and development of vision, strategies and policies to protect private data and information electronically either at 
the level of public sector restructuring the Government has developed a strong rules-based ICT tools and computerization systems and institution and linking them with each other and connected.

- Religious social factors, in Saudi Arabia, are preventing women to work with men in the same place but KSA has overcome this factor through the implementation of e-government through the provision of services via the Internet without the need for mixing between men and women as well as to be able to citizens to access to all services by using the internet applications.

- Cultural factor has been exploited by the Saudi government through supporting and improving education system as well as computing devices and distribute of free PCs and all citizens able to connect free to the Internet.

Each developing country can utilize this work in the same region to benefit from developed countries experience in order to implement their e-government program, especially those who are suffering from similar challenges derived by the previous mentioned factors.

As it is noted, developed countries have advanced egovernment levels of organizing and co-ordinations epically in their public sector infrastructure, public sector reforming, social and cultural factors. These advantages can be usefully for other countries, by studying same challenges and trying to find suitable solves for their egovernment programs' challenges by benefits from KSA experience.

\section{REFERENCES}

[1] Al-Hakim L., Global E-government: Theory, Applications and Benchmarking, University of South Queensland, Australia, published in Hershey PA, London, 2006.

[2] Al-Omari A., "E-Government Readiness Assessment Model," Journal of Computer Science, vol. 11, no. 2; pp. 841-845, 2006, ISSN 1549-3636.

[3] AL-Shehry A., "The Motivations for Change Towards EGovernment Adoption: Case Studies From Saudi Arabia,” EGovernment Workshop '06 (eGOV06), Brunel University, West London UB8 3PH, UK, September 112006.

[4] Chen Y., Chen H., Ching R., and Huang W., "E-Government Strategies in Developed and Developing Countries: An Implementation Framework and Case Study,” Journal of Global Information Management, Vol. 14, No. 1, pp. 23-46, 2006. http://dx.doi.org/10.4018/jgim.2006010102
[5] Cullen A., Elsheikh Y., and Hobbs D., "E-Government in Jordan: Challenges and Opportunities," e-Government Workshop '07 (eGOV’07), U.K., 2007.

[6] Eifert M., and Puschel J., National Electronic Government: Comparing Governance Structures in Multi-layer Administration, Routledge, 2004.

[7] Executive Office of the President Office of Management and Budget, E-Government Strategy, Washington, D.C. 20503, February 27, 2002.

[8] Fang Z., "E-Government in Digital Era: Concept, Practice, and Development,” International Journal of the Computer, the Internet and Management, Vol. 10, No. 2, pp. 1-22, Thailand, 2002.

[9] Furuholt. B., and Fathul, W., "E-government Challenges and the Role of Political Leadership in Indonesia: the Case of SrFuruholt,” Proceedings of the $41^{\text {st }}$ Hawaii International Conference on System Sciences, pp. 7-8, Norway, 2008.

[10] infoDev, E-Government Handbook for Developing Countries, The World Bank; 2002.

[11] Jussilainen M., "Knowledge Management at the Finnish Government: Now, Never or Later," Proceedings of the $67^{\text {th }}$ IFLA Council and General Conference, Boston, August16-25, 2001.

[12] Leitner C., "eGovernment in Europe: The State of Affairs," Presented at the egovernment 2003 conference-como, Italy 7-8 july, 2003.

[13] Ndou V., "E-Government for Developing Countries: Opportunities and Challenges," EJISDC: The Electronic Journal on Information Systems in Developing Countries, Vol. 18, No. 1, pp. 124,2004.

[14] OECD, Governance of Innovation Systems, Case, 2006, ISBN 9264035710.

[15] Sahraoui S., "Government In Saudi Arabia: Can It Overcome Its Challenges?” E-Government Workshop '06 (eGOV06), Brunel University, West London UB8 3PH, UK, September 112006.

[16] United Nations, "E-government Strategy Report;” New York, 2002.

[17] YESSER, "E-government guidelines manual for government agencies,” Saudi Arabia Kingdom, e-government program Riyadh, January 14, 2007.

\section{AUTHORS}

S. A. Nawafleh is an Assistant Professor at Department of Management Information System at University of Petra in Amman, Jordan (e-mail: sahem1977@hotmail.com).

R. F. Obiedat is an Assistant Professor at Department of Business Information System at University of Jordan, Amman, Jordan (e-mail: r.obiedat@ju.edu.jo).

O. K. Harfoushi is an Assistant Professor at Department of Business Information System at University of Jordan, Amman, Jordan (e-mail: o.harfoushi@ju.edu.jo).

Received 01 December 2011. Published as resubmitted by the authors 27 February 2012. 